Med Princ Pract 2013;22:603-604

DOI: $10.1159 / 000350422$

\section{Epicardial Adipose Tissue Should Be Evaluated with Other Inflammatory Markers in Patients with Subclinical Hypothyroidism}

\author{
Sevket Balta, Sait Demırkol, Ugur Kucuk, Zekeriya Arslan, \\ Murat Unlu, Fahri Gurkan Yesil \\ Department of Cardiology, Gulhane Medical Academy, \\ Ankara, Turkey
}

\section{Dear Editor,}

We have read the article 'Epicardial adipose tissue increased in patients with newly diagnosed subclinical hypothyroidism' with great interest [1]. The authors speculated that epicardial adipose tissue (EAT) might be increased in patients with subclinical hypothyroidism (SH) and it could relate to the development of cardiovascular disease in such patients due to higher levels of EAT in patients with $\mathrm{SH}$ than in controls. This may help explain the pathological mechanisms of thyroid dysfunctions related to coronary artery disease. Thanks to the authors for their contribution of the present study, which is successfully designed and documented.

The stages for treatment of $\mathrm{SH}$ are progression to overt hypothyroidism, poor quality of life related to nonspecific symptoms and suspected association with atherosclerosis. It is not known whether or not $\mathrm{SH}$ is related to risk for cardiovascular disease [2]. $\mathrm{SH}$ is associated with an increased risk of coronary artery disease events and coronary artery disease mortality in patients with high thyroid-stimulating hormone levels ( $\geq 10 \mathrm{mIU} / \mathrm{l})$ [3]. Cardiovascular diseases are the most important causes of mortality and morbidity in developed countries worldwide [4]. The EAT measured by echocardiography has been known to be associated with metabolic syndrome. Several clinical studies have revealed that there is a correlation between the amount of EAT and coronary atherosclerosis. Additionally, although the relationship between fatty liver disease and EAT has been reported previously [5], Korkmaz et al. [1] did not mention this relationship between EAT and fatty liver disease. The main cause of morbidity and mortality in kidney disease patients has been established to be cardiovascular disease [6]. On the other hand, in kidney disease patients, EAT was positively correlated with atherosclerosis, arterial stiffness and the presence of coronary artery calcification [7]. We think that the results of the study would be stronger, if the authors had mentioned these factors including liver and kidney function tests.

Other atherosclerotic factors that affect EAT that the authors did not mention include alcohol consumption, hypothyroidism, impaired glucose tolerance and higher inflammatory status such as an inflammatory disease, cardiac syndrome $\mathrm{X}$ and infection [8]. In addition, antihypertensive therapy (such as angiotensin-converting enzyme inhibitors, angiotensin receptor blockers, betablockers), statins and some medications such as used for weight loss and a medical history of drug addiction might affect EAT based on inflammation [9]. It would have been useful, if the authors had mentioned these factors.

Several studies have demonstrated that there has been a strong relationship between serum inflammatory markers and subclinical atherosclerosis [10]. So, EAT itself without other inflammatory markers may not provide information to clinicians about systemic inflammation. So, we think that it should be evaluated together with other serum inflammatory markers. We believe that these findings will enlighten further studies about EAT on $\mathrm{SH}$.

\section{References}

1 Korkmaz L, Sahin S, Akyuz AR, et al: Epicardial adipose tissue increased in patients with newly diagnosed subclinical hypothyroidism. Med Princ Pract 2013;22:42-46.

2 Kebapcilar L, Akinci B, Bayraktar F, et al: Plasma thiobarbituric acidreactive substance levels in subclinical hypothyroidism. Med Princ Pract 2007; 16:432-436.

3 Rodondi N, den Elzen WPJ, Bauer DC, et al: Subclinical hypothyroidism and the risk of coronary heart disease and mortality. JAMA 2010;304: 1365-1374.

4 Zubaid M, Rashed WA, Saad H, et al: Kuwait acute coronary syndromes registry: baseline characteristics, management practices and in-hospital outcomes of patients hospitalized with acute coronary syndromes in Kuwait. Med Princ Pract 2007;16:407-412.

5 Lai Y-H, Yun C-H, Yang F-S, et al: Epicardial adipose tissue relating to anthropometrics, metabolic derangements and fatty liver disease independently contributes to serum high-sensitivity C-reactive protein beyond body fat composition: a study validated with computed tomography. J Am Soc Echocardiogr 2012;25:234-241.

6 6 Román-García P, Rodríguez-García M, Cabezas-Rodríguez I, et al: Vascular calcification in patients with chronic kidney disease: types, clinical impact and pathogenesis. Med Princ Pract 2011;20:203-212.

7 Turan MN, Gungor O, Asci G, et al: Epicardial adipose tissue volume and cardiovascular disease in hemodialysis patients. Atherosclerosis 2013; 226:129-133.

8 Demirkol S, Balta S, Unlu M, et al: Evaluation of the mean platelet volume in patients with cardiac syndrome X. Clinics 2012;67:1019-1022.

-9 Karaman M, Balta S, Ay SA, et al: The comparative effects of valsartan and amlodipine on vWf levels and N/L ratio in patients with newly diagnosed hypertension. Clin Exp Hypertens 2013, E-pub ahead of print.

10 Acikgoz N, Ermis N, Yagmur J, et al: Uric acid level and its association with carotid intima-media thickness in patients with cardiac syndrome X. Med Princ Pract 2012;21:115-119.

\section{KARGER}

E-Mail karger@karger.com www.karger.com/mpp

\section{(c) 2013 S. Karger AG, Base} 1011-7571/13/0226-0603\$38.00/0

Karger

Open access

This is an Open Access article licensed under the terms of the Creative Commons Attribution-NonCommercialNoDerivs 3.0 License (www.karger.com/OA-license), applicable to the online version of the article only. Distribution for non-commercial purposes only.
Dr. Sevket Balta

Department of Cardiology, Gulhane School of Medicine

Tevfik Saglam Street

TR-06018 Etlik-Ankara (Turkey)

E-Mail drsevketb@gmail.com 


\section{Reply}

Levent Korkmaz ${ }^{a}$, Sinan Sahin ${ }^{b}$, Ali Riza Akyuz ${ }^{a}$, Murat Ziyrek ${ }^{b}$, Inan Anaforogluc, Mustafa Kose ${ }^{c}$, Hakan Erkan ${ }^{a}$,

Mustafa Tarık Ağaç ${ }^{a}$, Zeydin Acar ${ }^{a}$

aDepartment of Cardiology, Ahi Evren Thoracic and Cardiovascular Surgery Training and Research Hospital, and Departments of ${ }^{b}$ Cardiology and ${ }^{c}$ Endocrinology, Trabzon Numune Training and Research Hospital, Trabzon, Turkey

We would like to thank Balta et al. for their comment on our paper titled 'Epicardial adipose tissue should be evaluated with other inflammatory markers in patients with subclinical hypothyroidism' [1]. The main aim of our study was to investigate whether or not patients with subclinical hypothyroidism $(\mathrm{SH})$ had increased epicardial adipose tissue (EAT) that is closely related to coronary atherosclerosis [1]. We have found increased EAT in patients with $\mathrm{SH}$. As we mentioned in the limitation paragraph, our study was small and its design did not allow us to discuss in detail the pathological mechanisms of increased EAT in this patient pop- ulation. We agree that the confounding factors Balta et al. mentioned in their comment have direct and indirect effect on EAT. In addition to the systemic metabolic and inflammatory effect of $\mathrm{SH}$, its mechanical effect may play a role in the pathogenesis of coronary atherosclerosis [2]. We consider our study as a pilot study. Further studies are required to investigate the impact of the confounding factors on EAT in patients with $\mathrm{SH}$.

\section{References}

1 Korkmaz L, Sahin S, Akyuz AR, et al: Epicardial adipose tissue increased in patients with newly diagnosed subclinical hypothyroidism. Med Princ Pract 2013;22:42-46.

Prati F, Arbustini E, Labellarte A, et al: Eccentric atherosclerotic plaques with positive remodelling have a pericardial distribution: a permissive role of epicardial fat? A three-dimensional intravascular ultrasound study of left anterior descending artery lesions. Eur Heart J 2003;24:329_ 336.

Levent Korkmaz, MD, Department of Cardiology Ahi Evren Thoracic and Cardiovascular Surgery

Training and Research Hospital

Trabzon (Turkey)

E-Mail l.korkmaz@yahoo.com 